\title{
Variable habitat selection and movement patterns among Bullsnake (Pituophis catenifer sayi) populations in Saskatchewan
}

\author{
Tera L. Edkins ${ }^{1}$, Christopher M. Somers ${ }^{1}{ }^{*}$, Mark C. Vanderwel ${ }^{1}$, Miranda J. Sadar ${ }^{2}$, and \\ Ray G. Poulin 1,3
}

\author{
${ }^{1}$ Department of Biology, University of Regina, Regina, Saskatchewan S4S 0A2 Canada \\ ${ }^{2}$ Department of Clinical Sciences, College of Veterinary Medicine and Biomedical Sciences, Colorado State University, \\ Fort Collins, Colorado 80523 USA \\ ${ }^{3}$ Royal Saskatchewan Museum, Regina, Saskatchewan S4P 2V7 Canada \\ ${ }^{*}$ Corresponding author: chris.somers@uregina.ca
}

Edkins, T.L., C.M. Somers, M.C. Vanderwel, M.J. Sadar, and R.G. Poulin. 2018. Variable habitat selection and movement patterns among Bullsnake (Pituophis catenifer sayi) populations in Saskatchewan. Canadian Field-Naturalist 132(2): 126-139. https://doi.org/10.22621/cfn.v132i2.2036

\begin{abstract}
Pituophis catenifer sayi (Bullsnake) is a sparsely studied subspecies of conservation concern in Canada. Basic ecological information is lacking for P. c. sayi, which reaches its northern range limit in western Canada. To address this gap, we used radio-telemetry to examine space use and habitat selection in three populations of Bullsnakes in disjunct river valley systems (Frenchman, Big Muddy, and South Saskatchewan River Valleys) across their Saskatchewan range. Bullsnakes in two valleys used up to three times more space, travelled 2.5-times farther from overwintering sites, and had lower home range overlap than the third population. Landscape-level habitat selection was flexible, with snakes in all populations using both natural and human-modified habitats most frequently. Fine-scale habitat selection was also similar among populations, with Bullsnakes selecting sites within $1 \mathrm{~m}$ of refuges, regardless of whether they were natural or anthropogenic. Based on these results, Bullsnakes are flexible in their broad scale habitat use, as long as they are provided with fine scale refuge sites. The distribution of key seasonal resources appears to ultimately determine space use and habitat selection by Bullsnakes, regardless of the geographic location of the population.
\end{abstract}

Key words: Bullsnake; Pituophis catenifer sayi; grassland snakes; habitat selection; home range; space use; ecology

\section{Introduction}

Pituophis catenifer sayi (Bullsnake) is widespread throughout North America, but is of conservation concern in Canada where it reaches its northern range limit. The Committee on the Status of Endangered Wildlife in Canada assessed this subspecies of Gophersnake (Pituophis catenifer) as Special Concern (COSEWIC 2017), and there is a corresponding need for basic ecological and population studies. Information from more southerly populations in the USA shows that space requirements (home range size) are highly variable for Bullsnakes (Moriarty and Linck 1997; Fitch 1999; Rodriguez-Robles 2003; Kapfer et al. 2008, 2010). Kapfer et al. (2010) found that habitat quality was the most important factor affecting home range: Bullsnakes in high quality areas used less space. Bullsnake habitat selection also varies across their range, with some populations selecting south facing bluffs (Kapfer et al. 2008), while others primarily select open grassland habitats (Moriarty and Linck 1997; Rodriguez-Robles 2003). Space and habitat use have been examined for the closely related Great Basin Gophersnake (Pituophis catenifer deserticola) in Canada (Williams et al. 2012, 2014, 2015), though only two studies have addressed space use and habitat selection by Bullsnakes specifically. Both of these studies focussed on the same Bullsnake population in the Frenchman River Valley of southwestern Saskatchewan (Martino et al. 2012; Gar- diner et al. 2013). These Bullsnakes made long distance migrations between summer and winter habitats (up to $4 \mathrm{~km}$ ), selected for lowland pasture, slopes, and roads, and relied heavily on mammal burrows as refuge sites (Martino et al. 2012; Gardiner et al. 2013). Bullsnake home ranges in the Frenchman River Valley were substantially larger than more southerly populations in the United States (up to 99 fold difference; Martino et al. 2012). However, it is currently unknown whether the space use and habitat selection by snakes in this one area are broadly reflective of other populations occupying various landscapes across their Canadian range.

Snake space use and habitat selection are primarily based on the spatial distribution of key resources in the environment, and thus vary within and among populations (Carfagno and Weatherhead 2006; Bauder et al. 2015; Gomez et al. 2015). For example, Prairie Rattlesnakes (Crotalus viridis viridis) demonstrate variation in space use throughout their geographic range (displacement from overwintering site: 2.76 to $40 \mathrm{~km}$; home range: 18 to 109 ha; Bauder et al. 2015), with variation in prey availability being the suggested driver for these differences. Occupancy has also been linked to thermal requirements, with snakes selecting habitats conducive to optimizing thermoregulation (Burger and Zappalorti 1992; Blouin-Demers and Weatherhead 2001; Carfagno and Weatherhead 2006; Blouin-Demers and Weatherhead 2008; Cross et al. 2015). Retreat sites 
can be particularly critical as they provide suitable habitat for thermoregulation, refuge from predators, and increased foraging opportunities (Charland and Gregory 1995; Rodriguez-Robles 2003; Himes et al. 2006; Croak et al. 2013). The presence of refuges is especially important for snakes at northern latitudes, where the distribution and abundance of overwintering den sites often limits space use; snakes must move to and from suitable overwintering sites each year (Burger et al. 1988; Jorgensen et al. 2008; Bauder et al. 2015). As a result, the proximity of den sites relative to other key resources may be a primary determinant of space requirements in northern populations (Martino et al. 2012; Williams et al. 2012; Gardiner et al. 2013).

Space and habitat use by snakes may also be affected in various ways by human modification of the landscape or specific resources. The removal of native habitats can have negative impacts on abundance, activity patterns, and behaviours (Burger 2001; Kjoss and Litvaitis 2001; Beale et al. 2016). However, in many cases, responses vary depending on the ability of snakes to tolerate habitat changes and the quality of available resources (Driscoll 2004; Corey and Doody 2010). Ultimately, individuals may demonstrate increases, decreases, or no difference in the frequency of movements or extent of space use in human modified landscapes compared to natural landscapes (Corey and Doody 2010; Anguiano and Diffendorfer 2015; Smith et al. 2015; Ettling et al. 2016). Species may even be positively associated with modified habitats (Carfagno and Weatherhead 2006; Knoot and Best 2011). Snake response to habitat modification remains to be addressed thoroughly in areas with variation in human land use type and intensity.

Here, we quantify Bullsnake space use and habitat selection in populations from three different major river valley systems (Frenchman, Big Muddy, and South Saskatchewan River Valleys) in Saskatchewan, Canada. Our hypothesis was that habitat availability and landscape configuration, specifically the distance between overwintering dens sites and summer habitat, affect the space use and habitat selection of snakes. Consequently, we predicted that Bullsnake space use and habitat selection would vary among populations in the different river valleys, as these areas differ substantially in their available habitat types, landscape configurations, and intensity of human modification. Bullsnake spatial ecology has only been examined previously for one population in Canada, so our study aims to increase understanding of how these snakes use landscapes in various circumstances.

\section{Methods}

\section{Study species}

Bullsnakes are the largest snakes in Canada, reaching lengths of up to $2.5 \mathrm{~m}$ (Ernst and Ernst 2003). Bullsnakes are non-venomous constrictors that prey on small mammals, such as mice and ground squirrels, as well as birds, bird eggs, and reptiles. These snakes are diurnal during the majority of the summer, but may become more active during crepuscular periods when conditions are exceedingly hot and dry (July and August). Bullsnakes are widespread throughout the United States, with their range extending northward into Cana$\mathrm{da}$, across southeast Alberta to southwest and southcentral Saskatchewan (Ernst and Ernst 2003). Bullsnakes nest communally or individually under rocks, logs, and within self-excavated or mammal-created burrows (Ernst and Ernst 2003; Wright 2008). Bullsnakes overwinter in extensive mammal burrows or rock crevices (Ernst and Ernst 2003; Kapfer et al. 2008). In 2017 Bullsnakes were assessed as a species of Special Concern in Canada mainly due to threats of habitat loss and road mortality. Life history, behavioural, and population characteristics are thought to exacerbate the effects of these threats on Bullsnakes (COSEWIC 2017). As Bullsnakes den communally and may return to the same den each year, protection of these limited den sites is important for this subspecies.

\section{Study areas}

We studied Bullsnake space and habitat use in three major river valley systems across southern Saskatchewan, Canada: the Frenchman River Valley (FRV; in 2008 and 2009; data collected by Martino et al. 2012), the Big Muddy Valley (BMV; in 2015), and the South Saskatchewan River Valley (SSRV; in 2016; Figure 1). Bullsnakes rely on hibernacula in valley walls; the area between valleys likely does not contain suitable overwintering sites, and much of the habitat has been converted to agriculture. Bullsnakes in the three valleys are genetically differentiated, and no movement among populations is likely (Somers et al. 2017).

The study area in the FRV $\left(49^{\circ} 10^{\prime} 37^{\prime \prime} \mathrm{N}, 107^{\circ} 25^{\prime}\right.$ $33 " \mathrm{~W})$ is located within a community pasture. This area is composed of large tracts of native grass pasture, surrounded by cropland and roads (paved and gravel). We tracked snakes from two communal overwintering den sites within the native grassland pasture; both were located in valley hillsides with significant hill slumping and large burrow systems (Martino et al. 2012; Gardiner et al. 2013). Overwintering sites in the FRV are separated from the riparian zone in the centre of the valley by $\sim 3-4 \mathrm{~km}$. To use habitat other than the hills and slopes associated with valley walls, Bullsnakes in the FRV need to travel long distances, and almost always move downslope toward the valley centre (Martino et al. 2012; Gardiner et al. 2013).

The BMV $\left(49^{\circ} 12^{\prime} 55^{\prime \prime} \mathrm{N}, 105^{\circ} 12^{\prime} 09^{\prime \prime} \mathrm{W}\right)$ site is dominated by native grass pasture in the main valley and adjacent ravines. Cattle and horse ranches are located in the valley lowlands while the surrounding uplands have been converted for crop production. Bullsnakes are found on private land in this area. Ranchers in the BMV tend to protect Bullsnakes occupying their land due to the perceived rodent control benefits the snakes provide. We tracked snakes from den sites located in crevice and burrow systems within rock formations and valley hillsides. Communal den sites in the BMV 


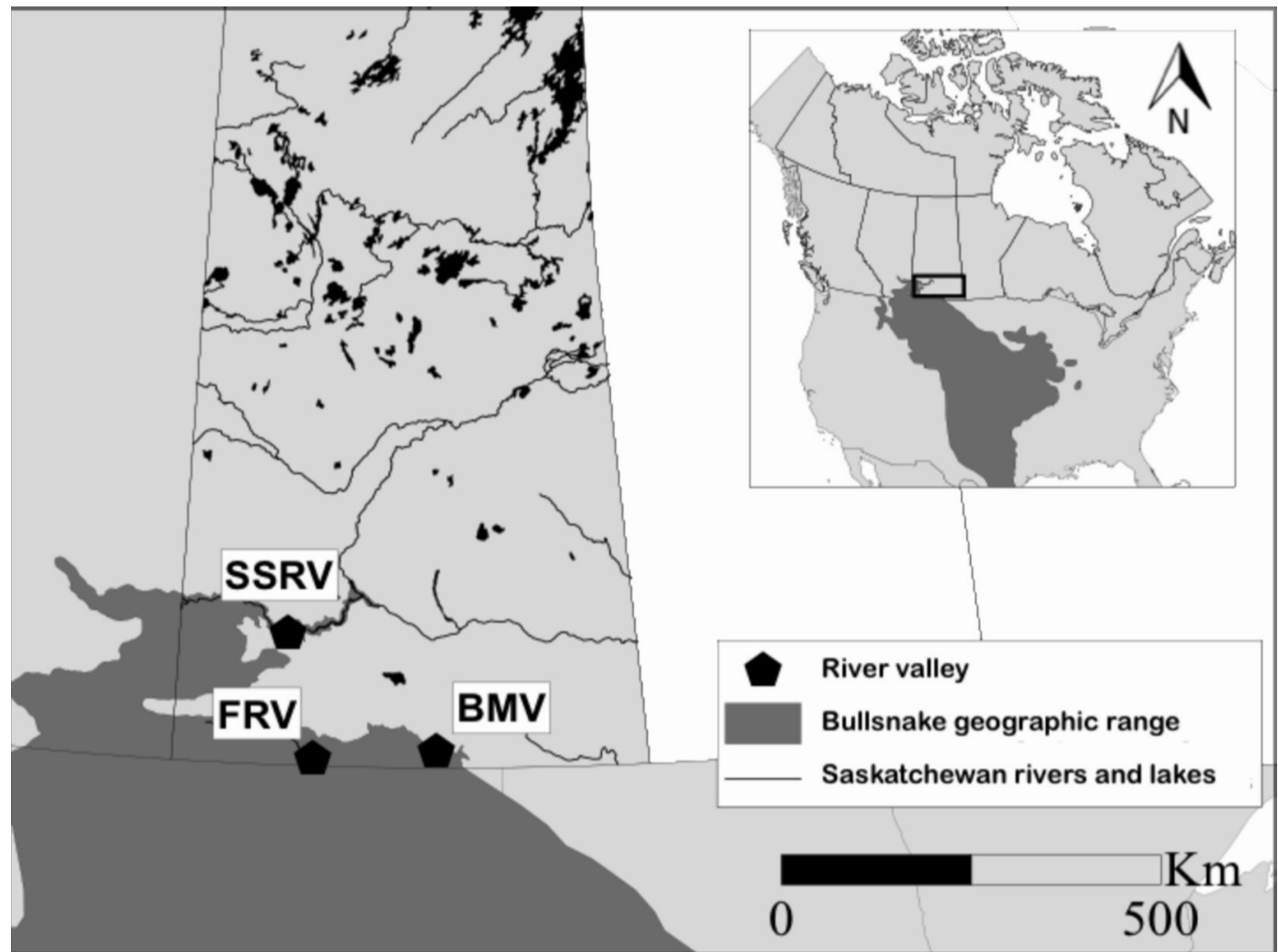

Figure 1. Location of study sites where Bullsnakes (Pituophis catenifer sayi) were tracked using radio-telemetry in southern Saskatchewan: Frenchman River Valley (FRV, 2008-2009, data collected by Martino et al. 2012), Big Muddy Valley (BMV, 2015), and South Saskatchewan River Valley (SSRV, 2016), indicated by the black pentagons. The North American Bullsnake range is highlighted in dark grey. Inset: the geographic range of Bullsnakes in Canada and the United States (dark grey).

were $<500 \mathrm{~m}$ from the valley base and in ranch farmyards. Contrary to the SSRV and FRV, no large river runs through the BMV.

The study area in the SSRV $\left(50^{\circ} 38^{\prime} 16^{\prime \prime} \mathrm{N}, 107^{\circ} 59^{\prime}\right.$ $28^{\prime \prime}$ ) is located in Saskatchewan Landing Provincial Park. The South Saskatchewan River has been converted into a large reservoir (Lake Diefenbaker) and this reservoir comprises the centre of Saskatchewan Landing Provincial Park, making it a popular area for summer recreational activities. The Provincial Park has $\sim 250000$ visitors per year (D. Silversides pers. comm. 8 November 2016). Native prairie dominates the main valley and adjacent coulees. Visitor areas (including campgrounds, a golf course, and cottages) are also found throughout the base of the valley. The uplands surrounding the park are used for cattle ranching and crop production. Den sites throughout the park are found within burrow systems (this study; Royal Saskatchewan Museum unpubl. data). Den sites are found in a wide range of locations, some of which are relatively close to the valley base $(\sim 100-600 \mathrm{~m}$ from Lake Diefenbaker) and in various topographies, from hillsides to flat, native grass fields (this study; Royal Saskatchewan Museum unpubl. data).

\section{Snake capture and transmitter implantation}

We located Bullsnakes during their active season (April to October) using foot searches and road surveys in the FRV from 2008 to 2009 (Martino et al. 2012), the BMV in 2015, and the SSRV in 2016. Upon capture, snakes were measured, weighed, sexed (after Schaefer 1934), and implanted with Passive Integrated Transponder (PIT) tags. Snakes were transported to a veterinary clinic and surgically implanted with Holohil model SI-2 (Carp, Ontario, Canada), 13-g radio-transmitters (similar to Lentini et al. 2011) by veterinary surgeons. In 2016, implantation protocols were modified, such that the transmitter wire was implanted within the body cavity of the snake instead of under the integument. This modification was made because subcutaneous implantation of the transmitter wire may lead to wire penetration of the skin and subsequent infection (Lentini et al. 2011). Snakes were only implanted if the diameter of the transmitter was $<50 \%$ of the body diameter at the implantation site, and the mass of the transmitter was $<5 \%$ of body mass. Snakes were allowed a minimum of $24 \mathrm{~h}$ recovery, upon which they were released at their original capture location. 


\section{Space use and movement patterns}

Following release, we relocated Bullsnakes every $48 \mathrm{~h}$ (when possible) for the duration of their summer active season. After snakes had returned to den sites in the fall (late August to early October), tracking was reduced to once every 1 to 2 weeks. Upon each relocation of a snake, we recorded universal transverse mercator (UTM) coordinates on a Garmin Legend HCx (Lenexa, Kansas, USA) handheld global positioning system (GPS) unit ( $\pm 2 \mathrm{~m})$. We quantified Bullsnake movement patterns using ArcGIS 10.3.1 (ESRI 2015). Maximum displacement by individual snakes from their respective den sites was calculated using the Point Distance Tool. The Geospatial Modelling Environment (GME; Beyer 2015) was used to estimate 100\% minimum convex polygons (MCP), as well as 50\% and 95\% kernel density estimates (KDE). MCP was calculated for individuals with at least 10 relocations (Himes et al. 2006; Parker and Anderson 2007; Kapfer et al. 2008, 2010; Martino et al. 2012) and KDE for individuals with at least 15 relocations (as in Gardiner et al. 2013). We defined relocations as any location to which a snake was tracked. We performed regression analysis to determine if the number of relocations per snake affected home range size (Kapfer et al. 2008). There was no significant positive relationship between home range size and the number of observations per snake (data not shown).

For the KDE, smoothing factors for each snake were estimated using the Plugin algorithm, which calculates the $\mathrm{X}$ and $\mathrm{Y}$ variances as well as the $\mathrm{X} / \mathrm{Y}$ covariance among relocation UTM coordinates. We used this method to calculate smoothing factors, as the commonly used least squared cross-validation (LSCV) algorithm tends to oversmooth and is not recommended for individuals with multiple relocations at the same site (Row and Blouin-Demers 2006). Using the Plugin algorithm to calculate a smoothing factor also produced 95\% KDE areas that were most similar to MCP areas, compared to the LSCV.

We calculated home range overlap for all river valleys using two different methods. The distances between Bullsnake MCP centroids were calculated using the Point Distance Tool, and the proportion of MCP shared was calculated using the Intersect Tool in ArcGIS. Distance between centroids and proportion of home range overlap was calculated for Bullsnakes occupying the same den sites. We constructed generalized linear models (GLM, with a gamma distribution) to estimate which variables influence snake home range size (MCP; 95\% KDE; 50\% KDE) and maximum displacement of snakes from den sites. Fixed effects were snake sex, snout-to-vent length, distance to nearest anthropogenic structure (i.e., farmyards, campgrounds, parking lots, cottages), and river valley. Distance to nearest anthropogenic structure was calculated as the distance between the centroid of an individual snake's MCP and the nearest anthropogenic structure point feature using the Point Distance Tool. After running the global model, we used Akaike's Information Criterion corrected for small samples size (AICc) for model selection. Competing models with $\triangle \mathrm{AIC}<10$ were model averaged and the $95 \%$ CI calculated (Burnham et al. 2011). We also performed gamma and beta regression analyses, respectively, to estimate which variables influence centroid distance and proportion of home range overlap.

Third order habitat selection: compositional analysis

Third order selection is defined as selection of habitats distinguishable by larger scale features, such as topography and vegetation type (Johnson 1980). Habitat selection at this scale was examined using compositional analysis; comparing the number of observations in each habitat type to the proportion of each habitat type available to Bullsnakes (Aebischer et al. 1993). Available habitat types were defined and distinguished prior to snake tracking using aerial imagery and confirmed in the field. Habitats were considered to be available to a snake if they were contained within a circular buffer zone centred on the den site that was calculated to be the maximum displacement by snakes in the corresponding population $(5 \mathrm{~km}$ radius buffer in the FRV; $1.3 \mathrm{~km}$ buffer in the BMV; $2.4 \mathrm{~km}$ buffer in the SSRV; Gomez et al. 2015). Third order habitat selection by Bullsnakes in the FRV was measured by Gardiner et al. (2013), where available habitats included riparian areas, hills/slopes, native lowland grass pasture, mudflats, roads, irrigation areas, native upland fields, crop fields, Prairie Dog (Cynomys ludovicianus) towns, and open water. Habitats available to snakes in the BMV included native grass pasture, crop fields, roads/road areas, hills/slopes/rock formations, trees/tall shrubs, and farmyards. SSRV habitats included native prairie, tame grass fields, mowed areas, human-developed areas (such as parking lots, buildings, and campgrounds), crop fields, roads/road areas, beach area, trees/tall shrubs, marshes/streams, and open water

Polygons encompassing available habitats within buffer zones were traced on a high-resolution satellite image (downloaded from https://www.flysask2.ca; accessed 10 September 2016) in ArcGIS. The proportion of each habitat within the buffer zone was calculated (defined as proportion available), as well as the proportion of total observations for each individual snake within each habitat type (defined as proportion used). We used the adehabitatHS package in $\mathrm{R}$ (Calenge 2006) to perform compositional analysis to test for non-random habitat use (selection) and rank habitats based on their selection by Bullsnakes.

\section{Fourth order habitat selection}

Fourth order habitat selection is defined as the selection of the immediate and local habitat, comprised of physical and ecological features that distinguish it from the surrounding environment (Johnson 1980). A used versus available study design was followed to quantify 
fourth order habitat selection (Aebischer et al. 1993; Thomas and Taylor 2006). Habitat characteristics were measured at sites that were used by snakes. Habitat measurements were only taken when a snake was tracked to a new location, defined as $\geq 20 \mathrm{~m}$ from the previous location. Habitat characteristics were measured within a $50 \times 50 \mathrm{~cm}$ quadrat at the used location and the percent grass, forb, shrub, and bare ground cover was estimated (to the nearest $5 \%$ ) within the quadrat. Maximum vegetation height, distance to nearest burrow, and distance to nearest shrub were also measured. Robel pole measurements of vegetation density were taken in each cardinal direction within the quadrat and averaged (Robel et al. 1970). These habitat variables have been used previously to assess snake habitat selection at a fine scale (Harvey and Weatherhead 2006; Moore and Gillingham 2006; Martino et al. 2012; Gardiner et al. 2015). The same habitat characteristics were also measured at available sites. Available sites were characterized as the halfway point along a straight line between a snake's previous location and new relocation ( $\geq 20 \mathrm{~m}$ away from previous location; Martino et al. 2012; similar to Gardiner et al. 2015), as this habitat would be 'available' to snakes during their travel to a new location. This was done to examine whether snakes were selecting habitat at a local scale (fourth order habitat selection) within their home range. To model habitat selection, we built generalized linear mixed models (GLMMs) with a binomial distribution in the package lme4 in R (Bates et al. 2015; R Core Team 2016). Habitat variables were fixed effects and individual snake ID was a random effect. We developed separate models for the BMV and SSRV. Martino et al. (2012) previously measured fourth order habitat selection by Bullsnakes in the FRV and we used those data.

Prior to running each model, a non-parametric Spearman's test was used to examine correlations between variables. We eliminated all variables that were correlated greater than $r_{s}=0.70$. As a result, percent bare ground was removed from all models, as it was negatively correlated with percent grass cover $\left(r_{s}=-0.70\right.$ to -0.92$)$. After eliminating the correlated variable and running the global GLMM, we used model selection based on AICc to compare all possible combinations of predictor variables. Competing models, with $\triangle \mathrm{AICc}$ $<10$, were model averaged to provide parameter estimates, importance values, and SE for all variables (Burnham et al. 2011). The 95\% CI were also calculated for all parameters.

\section{Results}

\section{Radio-telemetry}

Fourteen Bullsnakes (five females, nine males) were radio-tracked over the course of the active season in 2008 and 2009 in the FRV, with the total number of relocations per individual ranging from 10 to 50 (Table 1). In the BMV, seven Bullsnakes (four females, three males) were radio-tracked over the active season, with

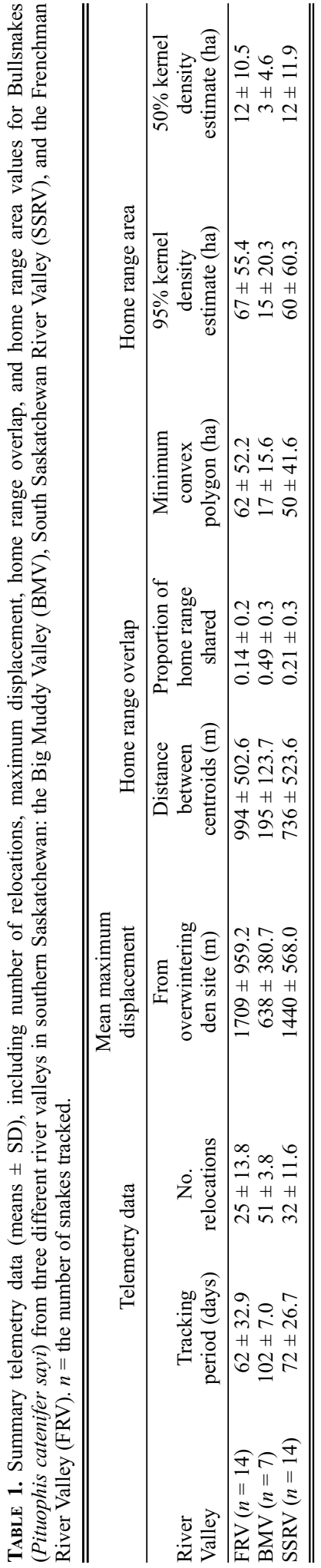


total relocations per individual ranging from 43 to 55 (Table 1). In the SSRV, 14 Bullsnakes (six females, eight males) were implanted with radio-transmitters. The number of relocations per snake ranged from 12 to 48 (Table 1). The maximum time between tracking events was 19 days in the FRV, seven days in the BMV, and six days in the SSRV.

\section{Space use and movement patterns}

The GLM indicated the largest factor affecting displacement from den sites by Bullsnakes was the river valley they occupied (Table 2). Bullsnakes in the FRV (493 to $3946 \mathrm{~m}$ ) and SSRV (661 to $2427 \mathrm{~m}$ ) had similar and relatively long maximum displacements from overwintering den sites, moving up to 2.7 times farther from dens than Bullsnakes in the BMV (Figure 2).

Fourteen snakes in the FRV, seven snakes in the BMV, and 14 snakes in the SSRV were relocated often enough to estimate MCPs, while $10 \mathrm{FRV}$, seven BMV, and $13 \mathrm{SSRV}$ snakes had enough relocations to estimate the $50 \%$ and $95 \%$ KDEs. Generalized Linear Models examining differences in home range size among Bullsnakes, regardless of home range estimator, were consistent with analyses of den site displacement, indicating river valley as the only fixed effect (Table 3; Tables S1 and S2). On average, Bullsnakes in the FRV and SSRV had MCP home ranges up to 3.7 times larger, $95 \%$ KDEs up to 4.5 times larger, and $50 \%$ KDEs up to 4.4 times larger than those in the BMV (Table 1; Figure 2).

Home range overlap was greater on average in the BMV, compared to the FRV and SSRV (Table 1; Figure 2). This was supported by generalized linear regression analyses, which demonstrated that the distance between centroids increased (FRV Estimate $=799.08$, $P<0.001 ;$ SSRV Estimate $=540.89, P<0.001)$ and the proportion of home range overlap decreased (FRV
Estimate $=-1.66, P<0.001 ;$ SSRV Estimate $=-1.39$, $P<0.001)$ in the FRV and SSRV compared to the BMV.

\section{Third order habitat selection}

Native lowland grass pasture, hills/slopes, and roads were used most frequently by Bullsnakes in the FRV (Figure 3a; Martino et al. 2012; Gardiner et al. 2013). Bullsnakes in the BMV also exhibited non-random habitat use $(\lambda=0.002, P=0.04)$; the most frequently used habitat types were farmyards and native grass pasture. On average, farmyards were selected 11 times more than expected; native grass pasture, roads, and hills/slopes were used in proportion to availability; and crop fields and treed areas were not used at all (Figure 3b). Similarly, Bullsnakes in the SSRV also exhibited non-random habitat use $(\lambda=0.014, P=0.01)$; the most frequently used habitats were beach area, native prairie, tame grass fields, human-developed areas (including buildings, parking lots, and campgrounds), mowed areas, and roads. Bullsnakes used beaches 91.6 times, tame grass fields 8.7 times, buildings 2.1 times, mowed areas 2.9 times, and roads 2.3 times more than expected based on availability (Figure 3c). Native prairie and marshes were used in proportion to availability; while treed areas and crop fields were used 8.7 times and two times less than expected (Figure 3c). Snakes were not observed in open water; however, they did make use of this habitat to travel from one side of Lake Diefenbaker to the other.

\section{Fourth order habitat selection}

The top model explaining differences between used and available sites in the BMV and SSRV included percent grass cover, vegetation density, and distance to the nearest burrow (Tables 4 and 5). The probability of occupancy increased with decreasing grass cover, increasing vegetation density, and decreasing distance to the

TABLE 2. Top generalized linear model, null model, and all models with $\Delta \mathrm{AIC} \leq 2$ evaluating the best predictor of maximum displacement from overwintering den sites by Saskatchewan Bullsnakes (Pituophis catenifer sayi). Fixed effects included river valley (BMV is reference valley), distance to nearest anthropogenic structure (dist. a), snout-to-vent length (svl), and snake sex $(\mathrm{M}=$ male). Number of model parameters $(\mathrm{K})$, AICc, difference in AICc from top model ( $\triangle \mathrm{AIC})$, Akaike weights, parameter estimates, SE, upper and lower 95\% CI, and importance values are presented. Factors with largest effect in bold.

\begin{tabular}{|c|c|c|c|c|c|c|}
\hline & Model & $\mathrm{K}$ & $\mathrm{AICc}$ & $\Delta \mathrm{AIC}$ & & Weights \\
\hline AIC model & Intercept only & 1 & 501.50 & 9.57 & & 0.00 \\
\hline \multirow[t]{3}{*}{ selection } & valley + dist. a & 2 & 491.92 & 0.00 & & 0.37 \\
\hline & valley & 1 & 492.95 & 1.03 & & 0.22 \\
\hline & valley + dist. $a+$ svl & 3 & 494.07 & 2.15 & & 0.13 \\
\hline \multirow[t]{7}{*}{ Model averaging } & Parameter & Estimate & $\mathrm{SE}$ & $\begin{array}{c}\text { Lower } \\
95 \% \text { CI }\end{array}$ & $\begin{array}{c}\text { Upper } \\
95 \% \text { CI }\end{array}$ & $\begin{array}{c}\text { Importance } \\
\text { values }\end{array}$ \\
\hline & (Intercept) & 6.34 & 0.42 & 5.62 & 7.05 & NA \\
\hline & FRV & 1.21 & 0.34 & 0.64 & 1.78 & 0.99 \\
\hline & SSRV & 0.88 & 0.27 & 0.43 & 1.34 & 0.99 \\
\hline & dist. a & 0.00 & 0.00 & 0.00 & 0.00 & 0.61 \\
\hline & svl & 0.00 & 0.00 & 0.00 & 0.01 & 0.26 \\
\hline & sexM & 0.00 & 0.09 & -0.16 & 0.16 & 0.19 \\
\hline
\end{tabular}




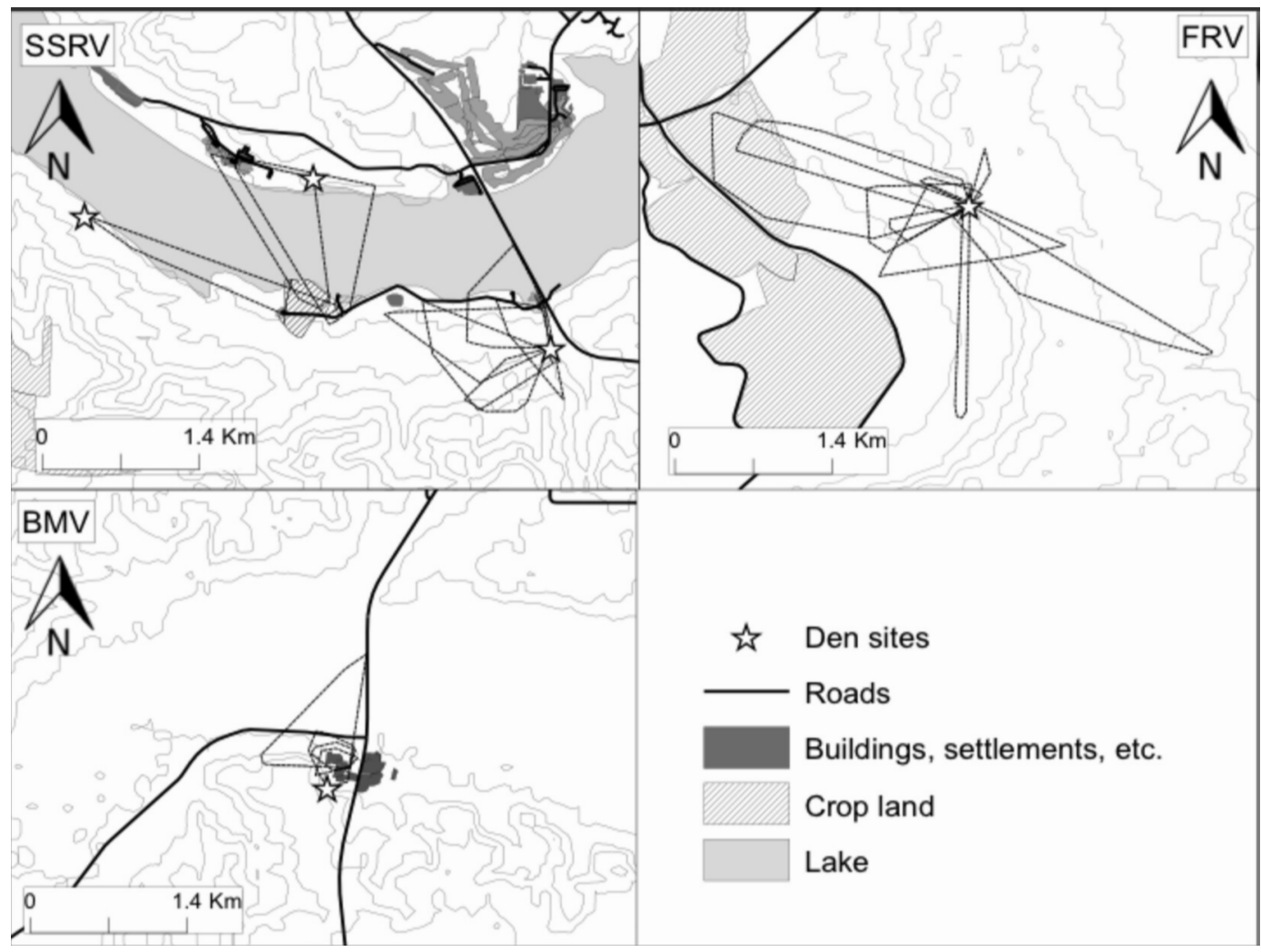

FigURE 2. Minimum convex polygons (MCPs) for Bullsnakes (Pituophis catenifer sayi) in the Frenchman River (FRV), South Saskatchewan River (SSRV), and Big Muddy (BMV) Valleys. MCPs are shown for nine FRV, eight SSRV, and four BMV Bullsnakes to depict variation in home ranges observed. Den sites are indicated by stars, roads by thick black lines, human developed areas by dark grey polygons, crop fields by crosshatched polygons, lakes by light grey polygons, and contours lines by light grey lines.

TABLE 3. Top generalized linear model, null model, and all models with $\triangle \mathrm{AIC} \leq 2$ evaluating the best predictor of Saskatchewan Bullsnake (Pituophis catenifer sayi) 95\% kernel density home range estimate. Fixed effects included river valley (BMV is reference valley), distance to nearest anthropogenic structure (dist. a), snout-to-vent length (svl), and snake sex $(\mathrm{M}=\operatorname{male})$. Number of model parameters $(\mathrm{K}), \mathrm{AICc}$, difference in AICc from top model ( $\triangle \mathrm{AIC})$, Akaike weights, parameter estimates, SE, upper and lower $95 \% \mathrm{CI}$, and importance values are presented. Factors with largest effect in bold.

\begin{tabular}{|c|c|c|c|c|c|c|}
\hline & Model & $\mathrm{K}$ & $\mathrm{AICc}$ & \multicolumn{2}{|c|}{$\Delta \mathrm{AIC}$} & Weights \\
\hline$\overline{\text { AIC model }}$ & Intercept only & 1 & 266.50 & 7.24 & & 0.01 \\
\hline \multirow[t]{3}{*}{ selection } & valley + svl & 2 & 259.42 & 0.00 & & 0.39 \\
\hline & valley & 1 & 261.43 & 2.16 & & 0.13 \\
\hline & Parameter & Estimate & $\mathrm{SF}$ & Lower & Upper & Importance \\
\hline Model & (Intercept) & 4.00 & 1.18 & 2.03 & 5.97 & $\mathrm{NA}$ \\
\hline \multirow[t]{5}{*}{ averaging } & FRV & 1.71 & 0.53 & 0.81 & 2.60 & 0.97 \\
\hline & SSRY & 1.32 & 0.44 & 0.57 & 2.07 & 0.97 \\
\hline & svl & -0.01 & 0.01 & -0.03 & 0.01 & 0.63 \\
\hline & dist. a & 0.00 & 0.00 & 0.00 & 0.00 & 0.28 \\
\hline & sexM & -0.09 & 0.24 & -0.49 & 0.31 & 0.25 \\
\hline
\end{tabular}



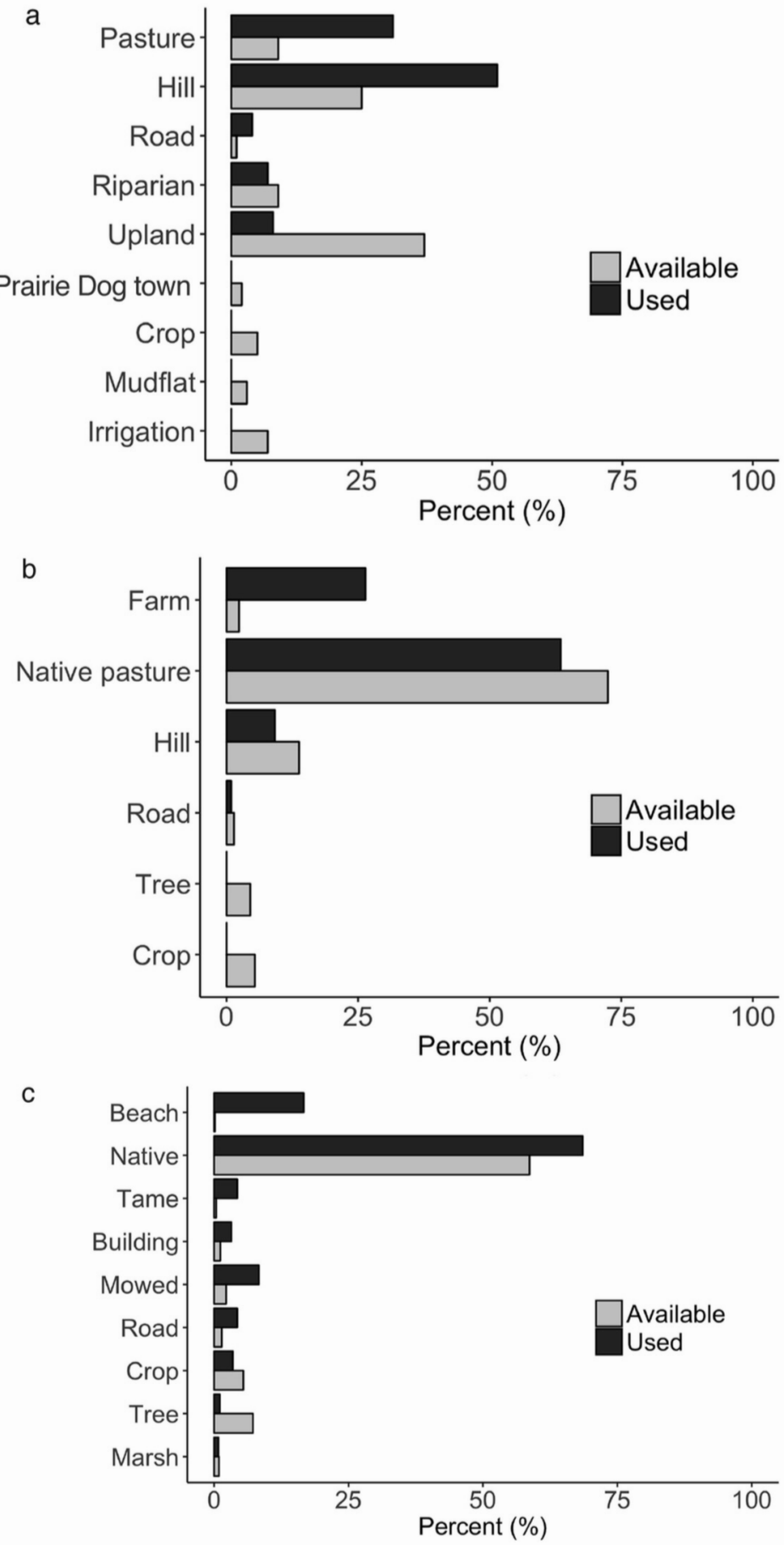

Figure 3. Third order habitat selection by Bullsnakes (Pituophis catenifer sayi) in three Saskatchewan river valleys. a. Percent of different habitats used and available within a $5 \mathrm{~km}$ buffer surrounding den sites in the Frenchman River Valley. b. Percent of different habitats used and available within a $1.3 \mathrm{~km}$ buffer surrounding den sites in the Big Muddy Valley. c. Percent of different habitat types used and available within a $2.4 \mathrm{~km}$ buffer surrounding den sites in the South Saskatchewan River Valley within Saskatchewan Landing Provincial Park. 
TABLE 4. Top generalized linear mixed model, null model, and all models with $\triangle \mathrm{AIC} \leq 2$ evaluating Bullsnake (Pituophis catenifer sayi) habitat selection in the Big Muddy Valley. Fixed effects included \% grass cover, \% shrub cover, \% forb cover, distance to nearest burrow, distance to nearest shrub, maximum vegetation height, and Robel pole vegetation density. Random effect was individual snake ID (|ind|). Number of model parameters (K), AICc, difference in AICc from top model ( $\triangle$ AIC), Akaike weights, parameter estimates, SE, upper and lower $95 \% \mathrm{CI}$, and importance values are presented. Factors with largest effect in bold.

\begin{tabular}{|c|c|c|c|c|c|c|}
\hline & \multicolumn{2}{|c|}{ Model } & $\bar{K}$ & $\overline{\mathrm{AICc}}$ & $\Delta \mathrm{AIC}$ & Weights \\
\hline$\overline{\mathrm{AIC} \text { model }}$ & Intercept $+\mid$ ind $\mid$ & & 2 & 373.88 & 108.72 & 0.00 \\
\hline selection & density $+\%$ grass $+b$ & |ind $\mid$ & 4 & 265.17 & 0.00 & 0.24 \\
\hline & dist. shrub + density & $\mathrm{s}+$ burrow $+\mid$ ind $\mid$ & 5 & 266.58 & 1.42 & 0.12 \\
\hline & $\max$ veg + density + & + burrow + |ind $\mid$ & 5 & 266.89 & 1.72 & 0.10 \\
\hline & $\%$ forb + density $+\%$ & burrow + |ind $\mid$ & 5 & 267.01 & 1.84 & 0.10 \\
\hline & $\%$ shrub + density + & + burrow + |ind $\mid$ & 5 & 267.25 & 2.09 & 0.08 \\
\hline $\begin{array}{l}\text { Model } \\
\text { averaging }\end{array}$ & Parameter & Estimate & SE & $\begin{array}{l}\text { Lower } \\
95 \% \text { CI }\end{array}$ & $\begin{array}{c}\text { Upper } \\
95 \% \mathrm{CI}\end{array}$ & $\begin{array}{l}\text { Importance } \\
\text { values }\end{array}$ \\
\hline & (Intercept) & 1.60 & 0.35 & 1.02 & 2.18 & NA \\
\hline & burrow & -0.51 & 0.09 & -0.66 & -0.37 & 0.99 \\
\hline & grass & -0.02 & 0.01 & -0.03 & -0.01 & 0.99 \\
\hline & density & 3.83 & 1.89 & 0.71 & 6.95 & 0.98 \\
\hline & dist.shrub & 0.01 & 0.01 & -0.02 & 0.03 & 0.33 \\
\hline & max.veg & 0.00 & 0.01 & -0.01 & 0.02 & 0.30 \\
\hline & forb & 0.00 & 0.01 & -0.02 & 0.02 & 0.27 \\
\hline & shrub & 0.00 & 0.01 & -0.02 & 0.02 & 0.26 \\
\hline
\end{tabular}

TABLE 5. Top generalized linear mixed model, null model, and all models with $\triangle \mathrm{AIC} \leq 2$ evaluating Bullsnake (Pituophis catenifer sayi) habitat selection in the South Saskatchewan River Valley. Fixed effects included \% grass cover, \% shrub cover, $\%$ forb cover, distance to nearest burrow, distance to nearest shrub, maximum vegetation height, and Robel pole vegetation density. Random effect was individual snake ID (|ind|). Number of model parameters (K), AICc, difference in AICc from the top model ( $\triangle \mathrm{AIC})$, Akaike weights, parameter estimates, SE, upper and lower $95 \% \mathrm{CI}$, and importance values are presented. Factors with largest effect in bold.

\begin{tabular}{|c|c|c|c|c|c|c|c|c|}
\hline & \multicolumn{4}{|c|}{ Model } & $\mathrm{K}$ & $\mathrm{AICc}$ & $\Delta \mathrm{AIC}$ & Weights \\
\hline \multirow{10}{*}{$\begin{array}{l}\text { AIC model } \\
\text { selection }\end{array}$} & \multirow{7}{*}{\multicolumn{4}{|c|}{$\begin{array}{l}\text { intercept }+\mid \text { ind } \mid \\
\text { burrow }+\% \text { forb }+\% \text { grass }+ \text { max veg }+ \text { density }+\mid \text { ind } \mid \\
\text { burrow }+\% \text { grass }+ \text { max veg }+ \text { density }+\mid \text { ind } \mid \\
\text { burrow }+\% \text { forb }+\% \text { grass }+ \text { density }+\mid \text { ind } \mid \\
\text { burrow }+\% \text { grass }+ \text { max veg }+ \text { density }+\% \text { shrub }+\mid \text { ind } \mid \\
\text { burrow }+\% \text { forb }+\% \text { grass }+ \text { max veg }+ \text { density }+\% \text { shrub }+\mid \text { ind } \mid \\
\text { burrow }+\% \text { forb }+\% \text { grass }+ \text { density }+\% \text { shrub }+\mid \text { ind } \mid\end{array}$}} & 2 & 539.07 & 123.86 & 0.00 \\
\hline & & & & & 6 & 415.24 & 0.00 & 0.11 \\
\hline & & & & & 5 & 415.31 & 0.07 & 0.11 \\
\hline & & & & & 5 & 415.44 & 0.20 & 0.10 \\
\hline & & & & & 6 & 415.78 & 0.54 & 0.09 \\
\hline & & & & & 7 & 416.23 & 0.99 & 0.07 \\
\hline & & & & & 6 & 416.53 & 1.30 & 0.06 \\
\hline & \multicolumn{4}{|c|}{ burrow $+\%$ grass + density $+\mid$ ind $\mid$} & 4 & 416.81 & 1.57 & 0.05 \\
\hline & \multirow{2}{*}{\multicolumn{4}{|c|}{$\begin{array}{l}\text { burrow }+ \text { dist. shrub }+\% \text { grass }+ \text { max veg }+ \text { density }+\mid \text { ind } \mid \\
\text { burrow }+ \text { dist. shrub }+\% \text { forb }+\% \text { grass }+ \text { max veg }+ \text { density }+\mid \text { ind } \mid\end{array}$}} & 6 & 417.16 & 1.92 & 0.04 \\
\hline & & & & & 7 & 417.18 & 1.95 & 0.04 \\
\hline \multirow{9}{*}{\multicolumn{2}{|c|}{ Model averaging }} & Parameter & Estimate & SE & $\begin{array}{l}\text { Lower } \\
95 \% \mathrm{CI}\end{array}$ & $\begin{array}{l}\text { Upper } \\
95 \% \text { CI }\end{array}$ & \multicolumn{2}{|c|}{$\begin{array}{c}\text { Importance } \\
\text { values }\end{array}$} \\
\hline & & (Intercept) & 0.98 & 0.35 & 0.41 & 1.55 & & NA \\
\hline & & burrow & -0.16 & 0.02 & -0.19 & -0.13 & & 0.99 \\
\hline & & grass & -0.01 & 0.01 & -0.02 & 0.00 & & 0.89 \\
\hline & & density & 0.81 & 0.29 & 0.33 & 1.29 & & 0.98 \\
\hline & & max.veg & 0.01 & 0.01 & 0.00 & 0.02 & & 0.58 \\
\hline & & forb & 0.02 & 0.02 & -0.02 & 0.05 & & 0.56 \\
\hline & & shrub & 0.00 & 0.01 & -0.01 & 0.01 & & 0.38 \\
\hline & & dist.shrub & 0.00 & 0.01 & -0.01 & 0.01 & & 0.27 \\
\hline
\end{tabular}

nearest burrow. The model-averaged 95\% CI for distance to nearest burrow, percent grass cover, and vegetation density did not pass through zero for both river valleys and the importance values for these three variables were greater than 0.8 (Tables 4 and 5). Bullsnakes were most likely to be found within $1 \mathrm{~m}$ of a burrow or other refuge site $(76 \%$ of the time in BMV, $73 \%$ of the time in SSRV).

\section{Discussion}

Bullsnake space use and movement patterns vary across their geographic range. Two populations in our study used more space than Bullsnakes in more southerly areas (Moriarty and Linck 1997; Fitch 1999; Rodriguez-Robles 2003; Kapfer et al. 2008; mean MCP: $34.43 \pm 27$ ha, mean 95\% KDE: $71.81 \pm 62$ ha), while the third population used less or similar space compared 
to southern populations. As such, northern populations do not appear to consistently tend towards larger home ranges, as originally suggested (Martino et al. 2012; Gardiner et al. 2013). We also found individual variation in snake space use patterns within and among sites even over a small geographic scale, similar to what has been previously observed (Bauder et al. 2015; Gomez et al. 2015). Some snakes used very little space, similar to southern populations (Rodriguez-Robles 2003; Kapfer et al. 2008), while others required much larger home ranges (MCP up to $175 \mathrm{ha}$ ). Williams et al. (2012) found similar variation in space use among neighbouring populations of the closely related Great Basin Gophersnake. In the case of our study and Williams et al. (2012), variation in home range size was strongly associated with study site, and appears to be the result of corresponding variation in distance between overwintering and summer habitats/resources.

Multiple factors may be driving this variation in Bullsnake space use, including den/nest site connectivity and prey availability. Previously, prey was identified as a driver of snake space use, with smaller home ranges in areas of higher prey availability (Brown et al. 2005; Wisler et al. 2008; Baxley and Qualls 2009; Ettling et al. 2016). Though no formal surveys were conducted, we observed abundant prey in the den-adjacent farmyards occupied by Bullsnakes in the BMV. We also observed mating and gravid Bullsnakes in this area. This suggests that the smaller home ranges of Bullsnakes in the BMV may be due to a tighter spatial connection between seasonal resources (i.e., overwintering dens and prey/nest sites). Higher resource availability in a small area near den sites in the BMV also corresponds with our home range overlap data (Figure 2). Bullsnakes in the BMV had higher home range overlap, in addition to smaller home ranges, suggesting a sufficient availability of resources capable of supporting individuals in close proximity to dens. In contrast, summer and overwintering activity centres (in terms of the $95 \%$ KDE) were separate in the FRV and SSRV, resulting in seasonal migrations (as described in Gardiner et al. 2013). Home range overlap was also lower, with snakes using different areas during the active season. Snakes have been observed to migrate seasonally to locate prey in areas of low prey density (Duvall et al. 1990), similar to what we observed in the FRV and SSRV. Williams et al. (2012) also suggested that Great Basin Gophersnake movements differed among sites due to differences in food availability and predation pressures. In addition, Kapfer et al. (2010) suggested that Bullsnake space use may be driven by thermoregulatory and refuge needs. Regardless of driving factor, the placement of den sites in relation to active season resources appears to be a primary determinant of Bullsnake space use.

Bullsnakes are flexible in their broad scale habitat use. Here, we found various human-modified habitats to be selected for by snakes in the BMV and SSRV, in addition to habitats dominated by native vegetation that were the most frequently used, though not necessarily selected because they were typically used according to their availability (Figure $3 \mathrm{~b}$ and c). Comparably, Bullsnakes in the FRV selected primarily for native habitats, in addition to roads (Figure 3a; Gardiner et al. 2013). Similarly, in Canada, Great Basin Gophersnakes use primarily native grassland habitat, in addition to slopes (Williams et al. 2014, 2015). Previous studies in southern range areas have also found Bullsnakes to use primarily native grassland habitats (Moriarty and Linck 1997; Rodriguez-Robles 2003; Kapfer et al. 2008). Slopes with native vegetation in particular appear to provide important overwintering habitat for Bullsnakes (Kapfer et al. 2008; Martino et al. 2012; Gardiner et al. 2013; our study). As such, native grassland habitat appears to be universally important for Bullsnakes across their range.

Retreat sites are an important habitat feature for Bullsnakes. Snakes in the BMV and SSRV selected for sites in close proximity to retreat sites, regardless of other habitat features or whether the refuge itself was natural (mammal burrow) or anthropogenic (under walkways, cement pads, stacked rocks). Bullsnakes in the FRV also demonstrated a dependence on retreat sites, as did Eastern Yellow-bellied Racers (Coluber constrictor flaviventris) and Prairie Rattlesnakes in the same areas (Martino et al. 2012; Gardiner et al. 2015). Suitable retreat sites are an important habitat feature for snakes, as they provide refuge from extreme temperatures and benefit thermoregulation (Huey et al. 1989; Webb and Shine 1998; Himes et al. 2006; Blouin-Demers and Weatherhead 2008; Croak et al. 2013). In our study, Bullsnakes remained near retreat sites (within $1 \mathrm{~m}$ ), even when snakes were not located directly within the retreat site itself. This would be beneficial for thermoregulation, as it would allow snakes to move in and out of refuges, depending on their physiological and thermoregulatory needs (Blouin-Demers and Weatherhead 2001). Remaining close to retreat sites, particularly burrows, would also benefit Bullsnakes by allowing them to avoid predators and hunt rodent prey that occupy the burrows (Moriarty and Linck 1997; RodriguezRobles 2002; Heard et al. 2004; Himes et al. 2006). Of the retreat sites used by Bullsnakes, many were created via excavation by mammals. Large burrow networks may also be used as overwintering sites (Moriarty and Linck 1997; Williams et al. 2015). As a result, snake reliance on mammal-created refuge sites supports the importance of burrowing mammals, such as the Richardson's Ground Squirrel (Urocitellus richardsonii), Nuttall's Cottontail (Sylvilagus nuttallii nuttallii), and American Badger (Taxidea taxus), for Bullsnake survival.

Vegetation density and grass cover also appear to affect fine scale habitat selection by Bullsnakes. Decreased grass cover at selected sites in the BMV and SSRV is most likely a consequence of Bullsnake retreat site selection. The majority of retreat sites are typically 
grass free; bare ground surrounds excavated burrow entrances and anthropogenic retreat sites are constructed of cement and other materials, with little vegetation. Increased vegetation density on selected sites in our study likely reflects shrub cover, particularly the dense sagebrush common in our study areas. Snakes have previously been observed to select for sites within close proximity to shrubs as well as retreat sites (Harvey and Weatherhead 2006; Martino et al. 2012; Gardiner et al. 2015) and many of the excavated burrows used by Bullsnakes in the BMV and SSRV were located at the base of shrubs, suggesting their potential benefit. One such benefit may be thermoregulation; as sun penetrates the shrubs and warms the snake, the shrub itself provides additional cover from predators (Huey et al. 1989). Burrows located beneath shrubs may also receive structural support from roots, which may be important for snakes in areas of high cattle density, such as the BMV.

The introduction of human-modified habitats and anthropogenic features is potentially beneficial to snakes. For example, snakes in the SSRV were found under walkways, in parking lots under cement blocks, and under buildings. Snakes using these retreat sites occupied them over relatively long periods of time (weeks), potentially indicating that they were suitable for thermoregulation and for meeting other needs. Previous research has found that snakes use artificial structures on the landscape, such as buildings and wells, as overwintering den sites (Woodbury and Parker 1956; Costanzo 1986; Burger et al. 1988). Modified habitats may also yield increased prey densities, which in turn attract and benefit snakes (Corey and Doody 2010). However, use of these habitats may also be costly for snakes. The use of anthropogenic habitat features in areas of high human activity could potentially increase risk of mortality via snake-vehicle collisions or human persecution. The consumption of rodent prey (e.g., ground squirrels) in agricultural areas may also be detrimental, as snakes may be exposed to rodenticide poison through prey consumption (Bishop et al. 2016). When assessing how the introduction of modified habitats will affect snake populations, researchers should consider the potential threats to snakes making use of these introduced habitat features.

\section{Conclusions}

Bullsnake space requirements vary among populations as well as across their geographic range. Much of the time, data pertaining to space use by a species are based on one population or study site (Croak et al. 2013). Here, we highlight the importance of understanding the spatial ecology of different populations of the same species, as resource distribution may differ greatly among populations. These findings are also relevant to other snake species that demonstrate similar variability in space use (Jorgensen et al. 2008; Bauder et al. 2015; Gomez et al. 2015). As a result, conservation and management strategies developed for one population of a species or subspecies may not be applicable to others. Williams et al. (2012) found similar results, examining the effectiveness of wildlife habitat areas encompassing Great Basin Gophersnake den sites. Though the majority of gophersnakes were protected within these areas, certain individuals travelled outside of the allocated area (Williams et al. 2012). How to consider variance in habitat and space use among populations when developing conservation strategies remains to be addressed. A possible approach for implementing a more inclusive strategy would be to create protected buffers around den sites, based on the largest measured space use requirements for a species, to encompass both wide and narrow-ranging individuals and populations.

Bullsnakes are quite generalist in their habitat requirements, making use of a range of native and modified habitats as shown in the current and previous studies (Moriarty and Linck 1997; Rodriguez-Robles 2003; Kapfer et al. 2008; Martino et al. 2012; Gardiner et al. 2013). The spatial association among seasonal habitats appears to be an important determinant of Bullsnake space use. However, the specific active season resource requirements driving the seasonal migrations of Bullsnakes, or lack thereof, remain to be addressed. Measuring how active season resource availability varies among populations may be useful in uncovering the drivers of Bullsnake space and habitat use during the active season. At the local scale, retreat sites were a universally important habitat feature, regardless of refuge type (i.e., natural or anthropogenic). We recommend considering fossorial mammal populations when developing management strategies for Bullsnakes, as they are important for providing food and refuges. We also recommend considering the consequences of Bullsnakes potentially making use of anthropogenic habitat features and refuge sites. Overall, habitat features at the fine spatial scale appear to be an important determinant of Bullsnake habitat use, compared to habitat features at the landscape scale.

\section{Acknowledgements}

Thanks to L. Vermeylen, A. Pecorari, A. Gallon, D. Frier, and U. Goncin for their assistance in the field and to veterinarians Dr. T. Fisher and Dr. D. Parker for their services and expertise. Thanks to Dave Silversides, Saskatchewan Landing Provincial Park, for providing visitor estimates for the park. Snakes were captured under Saskatchewan Ministry of Environment Scientific/Academic Research permit number 13FW165. All animal handling and surgical procedures were approved by the President's Committee on Animal Care at the University of Regina (Animal Care and Use Protocol 13-02). Funding for this project was provided by the Royal Saskatchewan Museum Graduate Student Scholarship; the Friends of the Royal Saskatchewan Museum; the Saskatchewan Ministry of Environment, Fish, and Wildlife Development Fund; and Saskatchewan Landing Provincial Park. 


\section{Literature Cited}

Aebischer, N.J., P.A. Robertson, and R.E. Kenward. 1993. Compositional analysis of habitat use from animal radiotracking data. Ecology 74: 1313-1325. https://doi.org/10. 2307/1940062

Anguiano, M.O., and J.E. Diffendorfer. 2015. Effects of fragmentation on the spatial ecology of the California kingsnake (Lampropeltis californiae). Journal of Herpetology 49: 420-427. https://doi.org/10.1670/13-014

Bates, D., M. Maechler, B. Bolker, and S. Walker. 2015. Fitting linear mixed-effects models using lme4. Journal of Statistical Software 67: 1-48.

Bauder, J.M., H. Akenson, and C.R. Peterson. 2015. Movement patterns of prairie rattlesnakes (Crotalus v. viridis) across a mountainous landscape in a designated wilderness area. Journal of Herpetology 49: 377-387. https://doi.org/ $10.1670 / 13-153$

Baxley, D.L., and C.P. Qualls. 2009. Black pine snake (Pituophis melanoleucus lodingi): spatial ecology and associations between habitat use and prey dynamics. Journal of Herpetology 43: 284-293. https://doi.org/10.1670/08-074 R1.1

Beale, M., S. Poulin, C. Ivanyi, and G. Blouin-Demers. 2016. Anthropogenic disturbance affects movement and increases concealment in western diamondback rattlesnakes (Crotalus atrox). Journal of Herpetology 50: 216221. https://doi.org/10.1670/14-112

Beyer, H.L. 2015. Geospatial Modelling Environment (Version 0.7.4.0). Accessed 2 October 2016. http://www.spat ialecology.com/gme

Bishop, C.A., K.E. Williams, D.A. Kirk, P. Nantel, E. Reed, and J.E. Elliott. 2016. A population model of the impact of rodenticide containing strychnine on great basin gophersnakes (Pituophis catenifer deserticola). Ecotoxicology 25: 1390-1405. https://doi.org/10.1007/s10646-016-1690-2

Blouin-Demers, G., and P.J. Weatherhead. 2001. An experimental test of the link between foraging, habitat selection, and thermoregulation in black rat snakes Elaphe obsoleta obsoleta. Journal of Animal Ecology 70: 1006-1013. https: //doi.org/10.1046/j.0021-8790.2001.00554.x

Blouin-Demers, G., and P.J. Weatherhead. 2008. Habitat use is linked to components of fitness through the temperature-dependence of performance in ratsnakes (Elaphe obsoleta). Israel Journal of Ecology and Evolution 54: 361372. https://doi.org/10.1560/IJEE.54.3-4.361

Brown, G.P., R. Shine, and T. Madsen. 2005. Spatial ecology of slatey-grey snakes (Stegonotus cucullatus, Colubridae) on a tropical Australian floodplain. Journal of Tropical Ecology 21: 605-612. https://doi.org/10.1017/S0266467 405002671

Burger, J. 2001. The behavioral response of basking northern water (Nerodia sipedon) and eastern garter (Thamnophis sirtalis) snakes to pedestrians in a New Jersey park. Urban Ecosystems 5: 199-129. https://doi.org/10.1023/A:102233 9704784

Burger, J., and R.T. Zappalorti. 1992. Philopatry and nesting phenology of pine snakes Pituophis melanoleucus in the New Jersey pine barrens. Behavioral Ecology and Sociobiology 30: 331-336. https://doi.org/10.1007/BF00 170599

Burger, J., R.T. Zappalorti, M. Gochfeld, W.I. Boarman, M. Caffrey, V. Doig, S.D. Garber, B. Lauro, M. Mikovsky, C. Safina, and J. Saliva. 1988. Hibernacula and summer den sites of pine snakes (Pituophis melanoleucus) in the New Jersey pine barrens. Journal of Herpetology 22: 425-433. https://doi.org/10.2307/1564337

Burnham, K.P., D.R. Anderson, and K. P. Huyvaert. 2011 AIC model selection and multimodel inference in behavioral ecology: some background, observations, and comparisons. Behavioral Ecology and Sociobiology 65: 23-25. https://doi.org/10.1007/s00265-010-1029-6

Calenge, C. 2006. The package "adehabitat" for the R software: a tool for the analysis of space and habitat use by animals. Ecological Modelling 197: 516-519. https://doi.org/ 10.1016/j.ecolmodel.2006.03.017

Carfagno, G.L.F., and P.J. Weatherhead. 2006. Intraspecific and interspecific variation in use of forest-edge habitat by snakes. Canadian Journal of Zoology 84: 1440-1452. https://doi.org/10.1139/z06-124

Charland, M.B., and P.T. Gregory. 1995. Movements and habitat use in gravid and nongravid female garter snakes (Colubridae: Thamnophis). Journal of Zoology 236: 543561. https://doi.org/10.1111/j.1469-7998.1995.tb02731.x

Corey, B., and J.S. Doody. 2010. Anthropogenic influences on the spatial ecology of a semi-arid python. Journal of Zoology 281: 293-302. https://doi.org/10.1111/j.1469-79 98.2010.00705.x

COSEWIC (Committee on the Status of Endangered Wildlife in Canada). 2017. COSEWIC assessment and status report on the Bullsnake Pituophis catenifer sayi in Canada. COSEWIC. Ottawa, Canada. Accessed 6 December 2017. http://www.sararegistry.gc.ca/document/default e.cfm?documentID $=3280$.

Costanzo, J.P. 1986. Influences of hibernaculum microenvironment on the winter life history of the garter snake (Thamnophis sirtalis). Ohio Journal of Science 86: 199204.

Croak, B.M., M.S. Crowther, J.K. Webb, and R. Shine. 2013. Movements and habitat use of an endangered snake, Hoplocephalus bungaroides (Elapidae): implications for conservation. PLoS ONE 8(4): e61711. https://doi.org/10. 1371/journal.pone.0061711

Cross, M.D., K.V. Root, C.J. Mehne, J. McGowan-Stinski, and D. Pearsall. 2015. Multi-scale response of eastern massasauga rattlesnakes (Sistrurus catenatus) to prescribed fire. American Midland Naturalist 173: 346-362. https:// doi.org/10.1674/amid-173-02-346-362.1

Driscoll, D.A. 2004. Extinction and outbreaks accompany fragmentation of a reptile community. Ecological Applications 14: 220-240. https://doi.org/10.1890/02-5248

Duvall, D., M.J. Goode, W.K. Hayes, J.K. Leonhardt, and D.G. Brown. 1990. Prairie rattlesnake vernal migration: field experimental analyses and survival value. Natural Geographic Research 6: 457-469.

Ernst, C.H., and E.M. Ernst. 2003. Snakes of the United States and Canada. Smithsonian Books, Washington, DC, USA.

ESRI (Environmental Systems Research Institute). 2015. ArcGIS Desktop. Redlands, California, USA.

Ettling, J.A., L.A. Aghasyan, A.L. Aghaysan, and P.G. Parker. 2016. Spatial ecology of Armenian vipers, Montivipera raddei, in two different landscapes: human-modified and recovered-natural. Russian Journal of Herpetology 23: 93-102.

Fitch, H.S. 1999. A Kansas Snake Community: Composition and Changes over 50 Years. Krieger Publishing Co., Malabar, Florida, USA.

Gardiner, L.E., C.M. Somers, J.A. Martino, D.L. Parker, and R.G. Poulin. 2013. Balancing the dumbbell: summer 
habitats need protection in addition to winter dens for northern snake communities. Journal of Wildlife Management 77: 975-982. https://doi.org/10.1002/jwmg.555

Gardiner, L.E., C.M. Somers, D.L. Parker, and R.G. Poulin. 2015. Microhabitat selection by prairie rattlesnakes (Crotalus viridis) at the northern extreme of their geographic range. Journal of Herpetology 49: 131-137. https://doi. org/10.1670/12-266

Gomez, L., K.W. Larsen, and P.T. Gregory. 2015. Contrasting patterns of migration and habitat use in neighboring rattlesnake populations. Journal of Herpetology 49: 371376. https://doi.org/10.1670/13-138

Harvey, D.S., and P.J. Weatherhead. 2006. A test of the hierarchical model of habitat selection using eastern massasauga rattlesnakes (Sistrurus c. catenatus). Biological Conservation 130: 206-216. https://doi.org/10.1016/j.biocon. 2005.12.015

Heard, G.W., D. Black, and P. Robertson. 2004. Habitat use by the inland carpet python (Morelia spilota metcalfei: Pythonidae): seasonal relationships with habitat structure and prey distribution in a rural landscape. Austral Ecology 29: 446-460. https://doi.org/10.1111/j.1442-9993.2004.01 383. $\mathrm{x}$

Himes, J.G., L.M. Hardy, D.C. Rudolph, and S.J. Burgdorf. 2006. Movement patterns and habitat selection by native and repatriated Louisiana pine snakes (Pituophis ruthveni): implications for conservation. Herpetological Natural History 9: 103-116.

Huey, R.B., C.R. Peterson, S.J. Arnold, and W.P. Porter. 1989. Hot rocks and not-so-hot rocks: retreat-site selection by garter snakes and its thermal consequences. Ecology 70 : 931-944. https://doi.org/10.2307/1941360

Johnson, D.H. 1980. The comparison of usage and availability measurements for evaluating resource preference. Ecology 61: 65-71. https://doi.org/10.2307/1937156

Jorgensen, D., C.C. Gates, and D.P. Whiteside. 2008. Movements, migrations, and mechanisms: a review of radiotelemetry studies of prairie (Crotalus $v$. viridis) and western (Crotalus oreganus) rattlesnakes. Pages 303-316 in The Biology of Rattlesnakes. Edited by W.K. Hayes, K.R. Beaman, M.D. Cardwell, and S.P. Bush. Loma Linda University Press, Loma Linda, California, USA.

Kapfer, J.M., J.R. Coggins, and R. Hay. 2008. Spatial ecology and habitat selection of bullsnakes (Pituophis catenifer sayi) at the northern periphery of their geographic range. Copeia 2008: 815-826. https://doi.org/10.1643/CE-07-104

Kapfer, J.M., C.W. Pekar, D.M. Reineke, J.R. Coggins, and R. Hay. 2010. Modeling the relationship between habitat preferences and home-range size: a case study on a large mobile Colubrid snake from North America. Journal of Zoology 282: 13-20. https://doi.org/10.1111/j.1469-79 98.2010.00706.x

Kjoss, V.A., and J.A. Litvaitis. 2001. Community structure of snakes in a human-dominated landscape. Biological Conservation 98: 285-292. https://doi.org/10.1016/S00063207(00)00167-1

Knoot, T.G., and L.B. Best. 2011. A multiscale approach to understanding snake use of conservation buffer strips in an agricultural landscape. Herpetological Conservation and Biology 6: 191-201.

Lentini, A.M., G.J. Crawshaw, L.E. Licht, and D.J. McLelland. 2011. Pathologic and hematologic responses to surgically implanted transmitters in eastern massasauga rattlesnakes (Sistrurus catenatus catenatus). Journal of Wildlife
Disease 47: 107-125. https://doi.org/10.7589/0090-355847.1.107

Martino, J.A., R.G. Poulin, D.L. Parker, and C.M. Somers. 2012. Habitat selection by grassland snakes at northern range limits: implications for conservation. Journal of Wildlife Management 76: 756-767. https://doi.org/10.1002/jw mg.313

Moore, J.A., and J.C. Gillingham. 2006. Spatial ecology and multi-scale habitat selection by a threatened rattlesnake: the eastern massasauga (Sistrurus catenatus catenatus). Copeia 2006: 742-751. https://doi.org/10.1643/00458511(2006)6[742:SEAMHS]2.0.CO;2

Moriarty, J.J., and M. Linck. 1997. Reintroduction of bullsnakes into a recreated prairie. Pages 43-54 in Minnesota's Amphibians and Reptiles: Their Conservation and Status. Edited by J.J. Moriarty and D. Jones. Serpent's Tale Natural History Book Distributors, Lanesboro, Minnesota, USA.

Parker, J.M., and S.H. Anderson. 2007. Ecology and behavior of the midget faded rattlesnake (Crotalus oreganus concolor) in Wyoming. Journal of Herpetology 41: 41-51. https://doi.org/10.1670/0022-1511(2007)41[41:EABOTM] 2.0.CO;2

R Core Team. 2016. R: A language and environment for statistical computing. R Foundation for Statistical Computing, Vienna, Austria.

Robel, R.J., J.N. Briggs, A.D. Dayton, and L.C. Hulbert. 1970. Relationships between visual obstruction measurements and weight of grassland vegetation. Journal of Rangeland Management 23: 295-297. https://doi.org/10. 2307/3896225

Rodriguez-Robles, J.A. 2003. Home ranges of gopher snakes (Pituophis catenifer, Colubridae) in central California. Copeia 2003: 391-396. https://doi.org/10.1643/0045-85 11(2003)003[0391:HROGSP]2.0.CO;2

Row, J.R., and G. Blouin-Demers. 2006. Kernels are not accurate estimators of home-range size for herpetofauna. Copeia 2006: 797-802. https://doi.org/10.1643/0045-85 11(2006)6[797:KANAEO]2.0.CO;2

Schaefer, W.H. 1934. Diagnosis of sex in snakes. Copeia 1934: 181. https://doi.org/10.2307/1435852

Smith, R.M., J.R. Spotila, and W.F. Bien. 2015. Spatial ecology of northern pinesnakes (Pituophis m. melanoleucus) in disturbed and undisturbed habitats in the New Jersey pine barrens. Herpetologica 71: 19-25. https://doi.org/10.1655/ HERPETOLOGICA-D-13-00028

Somers, C.M., C.F. Graham, J.A. Martino, T.R. Frasier, S.L. Lance, L.E. Gardiner, and R.G. Poulin. 2017. Conservation genetics of the eastern yellow-bellied racer (Coluber constrictor flaviventris) and bullsnake (Pituophis catenifer sayi): river valleys are critical features for snakes at northern range limits. PLoS ONE 12(11): e0187322. https://doi.org/10.1371/journal.pone.0187322

Thomas, D.L., and E.J. Taylor. 2006. Study designs and tests for comparing resource use and availability II. Journal of Wildlife Management 70: 324-336. https://doi.org/10. 2193/0022-541X(2006)70[324:SDATFC]2.0.CO;2

Webb, J.K., and R. Shine. 1998. Using thermal ecology to predict retreat-site selection by an endangered snake species. Biological Conservation 86: 233-242. https://doi.org/ 10.1016/S0006-3207(97)00180-8

Williams, K.E., K.E. Hodges, and C.A. Bishop. 2012. Small reserves around hibernation sites may not adequately protect mobile snakes: the example of great basin gophersnakes (Pituophis catenifer deserticola) in British Columbia. Cana- 
dian Journal of Zoology 90: 304-312. https://doi.org/10. 1139/Z11-136

Williams, K.E., K.E. Hodges, and C.A. Bishop. 2014. Phenology and demography of great basin gophersnakes (Pituophis catenifer deserticola) at the northern edge of their range. Herpetological Conservation and Biology 9: 246256.

Williams, K.E., K.E. Hodges, and C.A. Bishop. 2015. Hibernation and oviposition sites of great basin gophersnakes (Pituophis catenifer deserticola) near their northern range limit. Journal of Herpetology 49: 207-216. https://doi.org/ $10.1670 / 13-162$
Wisler, C., U. Hofer, and R. Arlettaz. 2008. Snakes and monocultures: habitat selection and movements of female grass snakes (Natrix natrix l.) in an agricultural landscape. Journal of Herpetology 42: 337-346. https://doi.org/10. $1670 / 07-027.1$

Woodbury, A.M., and D.D. Parker. 1956. A snake den in cedar mountains and notes on snakes and parasitic mites. Herpetologica 12: 261-268.

Wright, J.D. 2008. Bullsnake, Pituophis catenifer sayi, nesting biology in Alberta. Canadian Field-Naturalist 122: 138-141. https://doi.org/10.22621/cfn.v122i2.572

Received 31 January 2018

Accepted 30 April 2018

\section{SUPPLEMENTARY MATERIAL:}

TABLE S1. Top generalized linear model, null model, and all models with $\triangle \mathrm{AIC} \leq 3$ evaluating the best predictor of Saskatchewan Bullsnake (Pituophis catenifer sayi) 50\% kernel density core area size.

TABLE S2. Top generalized linear model, null model, and all models with $\triangle \mathrm{AIC} \leq 2$ evaluating the best predictor of Saskatchewan Bullsnake (Pituophis catenifer sayi) minimum convex polygon home range size. 